\title{
Kompetensi Kerjasama Misi Lintas Budaya Misionaris PCK Dengan Pemimpin Gereja Lokal Indonesia
}

\author{
Dr. Choi Yong Sung \\ Sekolah Tinggi Teologi Pelita Dunia
}

\begin{abstract}
This research is a study of qualitative checking of cross-cultural missionary missionary PCK with Local Church Leaders in Indonesia.

Keywords: Cross-Culture, Missionaries, Indonesia.

Abstrak: Penelitian ini merupakan penelitian tentang mengecek secara kualitatif kerjasama misi lintas budaya Misionaris PCK dengan Pemimpin Gereja Lokal di Indonesia.
\end{abstract}

Kata Kunci: Lintas Budaya, Misionaris, Indonesia.

\section{Pendahuluan}

Sejarah perkembangan negara Korea baru terjadi sekitar dua abad belakangan. Pada masa sebelumnya, negara Korea dalam tekanan besar akibat permusuhan antara negara Cina dan Jepang. Harapan baru tumbuh setelah kedatangan para misionaris saat Korea menjadi negara tujuan misi. Oleh karena itu, sebagai bentuk balas budi atau bayar utang kepada misi, beberapa dekade belakangan ini Korea Selatan menjadi salah satu negara pengutus misionaris terbanyak ke seluruh dunia. Salah satu dari badan misi tersebut adalah Departemen Misi Sinode Presbyterian Church Of Korea (PCK).

Kebijakan Departemen Misi Sinode PCK mengharuskan setiap misionaris melakukan kerjasama dengan pemimpin gereja lokal di ladang misi. Salah satu dari ladang misi misionaris PCK adalah Indonesia. Misionaris awal yang datang ke Indonesia adalah Park Chang Hwan tahun 1971.1 Sejak saat itu, ada banyak misionaris diutus ke Indonesia sampai saat ini. Dari berbagai catatan dan cerita ditemukan bahwa tidak semua kerjasama ini berjalan dengan mulus. Ada beberapa misionaris yang memutuskan kembali ke Korea dengan alasan tertentu, ada yang memutuskan kerjasama secara sepihak dengan pemimpin lokal, dan berbagai konflik lain yang muncul selama

1 Park Chang Hwan datang atas permintaan Sinode Gereja Protestan di Indonesia bagian Barat (GPIB) pada tahun 1971 (김종국_Kim Jong Guk, 2011:43). Beliau ditugaskan untuk menjadi gembala jemaat di GPIB Sungai Liat Bangka. 
bekerjasama.

Hal ini dikarenakan kurangnya kompetensi lintas budaya dalam kerjasama misi antara misionaris Korea dengan pemimpin lokal. Kompetensi lintas budaya berarti kemampuan seseorang untuk berkomunikasi secara efektif dengan orang-orang dari kebudayaan lain (Deardroff, 2009: 56). Kompetensi ini diperlukan terutama dalam bidang kerjasama di antara orang-orang dari berbagai budaya (Deardroff, 2009: 122). Kompetensi yang dimaksud dapat berupa pengetahuan (kognitif), keahlian dalam bidang tertentu (psikomotorik), maupun dalam sikap (afektif). Menurut Byram yang paling penting dalam kompetensi lintas budaya adalah sikap seseorang.2 Selain itu diperlukan perubahan perspektif satu sama lain berdasarkan konteks di mana seseorang atau suatu kelompok berada sampai ke titik dimana satu sama lain dapat saling menghargai dan menerima perbedaan yang ada (Byram, 2006: 13). Kemampuan lintas budaya ini penting untuk mengatasi kemungkinan konflik yang muncul di antara orang-orang yang melakukan kerjasama lintas budaya (Deardroff, 2009: 117). Sementara kompetensi lain seperti pengetahuan dan keahlian mendukung di belakangnya (2001: 6).3

Tulisan ini merupakan bentuk aspirasi, kritikan dan sumbangsih pemikiran penulis bagi kerjasama misi Misionaris PCK pemimpin gereja lokal di Indonesia agar kerjasama dapat berjalan dengan baik dan berkesinambungan. Hasil dari tulisan ini penulis dapatkan dari tinjauan pustaka, refleksi pengalaman selama melayani secara lintas budaya di Indonesia, melalui wawancara dengan para misionaris Korea di Indonesia dan para pemimpin gereja lokal di Indonesia itu sendiri.

\section{Metode Penelitian}

Penelitian ini menggunakan pendekatan kualitatif, secara khusus kajian pustaka. Pendekatan ini diambil untuk memperoleh pemahaman kualitatif yang valid dan komprehensif bagi topik yang dibahas dalam penelitian ini.

2 Saat memasuki suatu budaya yang berbeda, orang-orang yang datang perlu memiliki sikap terbuka terhadap kebudayaan baru, mampu mengalahkan kecenderungan untuk tidak dapat mempercayai orang-orang yang berbeda budaya, tidak superior atau merasa budayanya yang paling baik, dll (Byram, 2001: 5).

3 Frasa ini terbagi menjadi beberapa kata penting yaitu: satu, Kompetensi. Secara umum, istilah kompetensi berarti kemampuan atau kapabilitas. Kata ini memberi indikasi kepada kepintaran atau kemampuan dalam melakukan suatu pekerjaan, serba tahu, terampil, dll (Parulian, 2008: 2, Hartanto, 2009: 429). Istilah ini juga memberi indikasi terhadap karakteristik seseorang yang berkaitan dengan efektivitas prima atau kinerja individu dalam pekerjaannya, dapat juga mengarah kepada kapasitas seseorang yang diperoleh dari proses belajar terhadap bidang yang ditekuninya. Kemampuan ini dapat diperoleh melalui proses latihan kognitif, afektif dan psikomotorik. Kompetensi seseorang tidak didapat dengan sendirinya, melainkan melalui proses yang memakan waktu tertentu namun dapat dilihat dan diukur perkembangannya (Pianda: 2018, 30-31). Dua, Lintas budaya dalam KBBI berarti pertemuan dua budaya atau lebih yang berlangsung sangat cepat (2008:833). Lintas budaya yang penulis maksud di sini adalah pertemuan atau perjumpaan yang terjadi antara orang-orang yang berbeda budaya. 


\section{Pembahasan: Dasar Teologis Alkitabiah Kompetensi Kerjasama Misi Lintas Budaya}

\section{Rekan Kerja Sebagai Bagian Integral dalam Kerjasama Misi Lintas Budaya}

Dalam kerjasama misi, rekan kerja adalah faktor terpenting dalam mendukung keberhasilan di ladang misi.4 Sebagai rekan kerja, setiap orang yang bekerjasama perlu saling peduli dan saling menghargai kehidupan masing-masing. Istilah partner atau

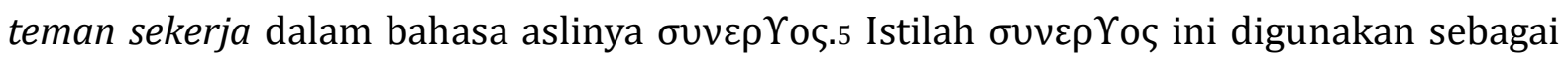
suatu istilah umum baik dalam bidang politik, ekonomi, sosial, dan berbagai aspek kehidupan untuk menggambarkan kerjasama yang dilakukan oleh orang-orang berbeda untuk satu tujuan produktif, efektif atau maksimal tertentu. Bapa-bapa gereja lainnya tidak menggunakan istilah ini secara khusus (Rollof, 1965: 122; 조경철_Cho Kyung Chul, 2005:103) karena merupakan terminologi yang muncul dari pikiran Paulus. Paulus dalam hal ini bersinergi dengan orang-orang di sekitarnya dengan tujuan agar misi Kerajaan Allah tercapai secara efektif.

Partnership merupakan hubungan antara manusia yang didalamnya terdapat program kerja atau tanggungjawab bersama untuk satu tujuan yang baik (Filipi 2:3). Kerjasama misi terjadi ketika anggota tubuh Kristus akan "dengan sukacita saling menolong" satu sama lain (Muller, 2006:717). Hal ini menyangkut kepedulian dan saling memberi manfaat satu dengan yang lain. Oleh karena itu, dalam kerjasama misi, mereka mengizinkan setiap rekan kerja untuk berpartisipasi dalam setiap kegiatan dalam perkumpulan misi sebagai rekan dalam misi untuk memperlengkapi misi bagi setiap orang percaya di seluruh dunia (Muller, 2006:716).

\section{Dasar Alkitabiah Kerjasama Misi Lintas Budaya}

Berikut ini, penulis melakukan beberapa tinjauan terhadap beberapa pengalaman misionaris yang terdapat dalam Alkitab, seperti:

4 Pengertian dasar rekan atau partner digunakan secara luas oleh Max Warren dalam tulisannya yaitu dengan istilah parcener atau pewaris bersama. Istilah parcener mengindikasikan bahwa orang-orang yang melakukan kerjasama misi adalah sama-sama merupakan pewaris yang sah dari Kerajaan Allah (1955:12). Oleh karena itu, jika orang-orang yang terlibat dalam kerjasama dapat bekerjasama dengan baik maka mereka sudah bekerjasama dalam cara yang benar. Dalam melakukan kerjasama misi, dunia misi menggunakan teori 4P yang diperkenalkan oleh Ralph Winter sebagai hal yang penting dalam melakukan kerjasama. Keempat hal itu antara lain: pioneer, parent, partner, participant sekaligus menjadi tingkatan hubungan dalam misi (1999: 219).

5 Istilah ini digunakan oleh Paulus sebanyak lima kali dan dua di antaranya ada dalam surat-surat Penggembalaan Paulus (Roma 16:9, 21; II Kor 6:1, Filipi 2:25, Filemon 1:1) dalam gereja mula-mula dan digunakan juga dua kali dalam tulisan Markus (Markus 16:20) dan Yakobus (Yakobus 2:22). Istilah $\sigma v v \varepsilon \rho$ Yos atau temanku sekerja atau kawan sekerja juga muncul sebanyak 18 kali dalam Perjanjian Baru dan empat belas di antaranya merupakan tulisan Paulus secara khusus (Roma 8:28, 16:3, 9, 21; I Kor 3:9, 16:16 ; 2 Kor 1: 24, 6:1, 8:23; Filipi 2:25; 4:3; I Tes 3:2; Filemon 1,24) dan tiga lainnya digunakan oleh Paulus untuk jemaat di Kolose 4:11 pada perjalanan kedua, Markus dalam Markus 16:20, Yakobus dalam Yakobus 2:22 dan oleh Yohanes dalam III Yohanes 8. 
a. Inisiatif dan/ atau Motivasi Kompetensi Kerjasama Misi Lintas Budaya

Motivasi utama sekaligus inisiatif misi lintas budaya pada hakikatnya berasal dari Allah sendiri. Dalam PL, Alkitab mencatat beberapa peristiwa penting yang menjadi indikasi terhadap hal ini. Misalnya peristiwa pemanggilan Abram dalam Kejadian 12. Misi yang dilakukan Abram adalah misi sentripetal karena gerakan misi yang ini berasal dari luar daerah menuju ke pusat yaitu ke Abram, Ishak, Yakub dan/ atau Israel. Inilah gambaran misi PL. Namun lebih dari itu adalah, inisiatif awal sekaligus motivasi untuk menjadikan Abram sebagai pusat misi sentripetal berasal dari Allah sendiri (Kej 12: 3) (Wahono, 2011: 95). PB mencatatkan amanat Yesus bagi para murid untuk pergi ke ujung-ujung bumi (KPR 1:8). Perjalanan misi Sentrifugal ini dimulai dari Yudea yang satu budaya dengan para murid, Samaria yang mulai sedikit berbeda budaya dengan mereka dan ujung bumi yang menggambarkan perbedaan budaya dengan para murid. Pada praktisnya, para murid akhirnya melakukan perjalanan lintas budaya sampai ke berbagai daerah dan benua di luar Asia. Perintah ini, tidak lain merupakan inisiatif Allah. Karena itu, motivasi dan/ atau inisiator utama untuk melakukan misi lintas budaya adalah Allah.

\section{b. Abraham sebagai Misionaris Lintas Budaya}

Abram diminta untuk berangkat dari Haran menuju ke tanah Kanaan. Namun untuk sampai ke tanah Kanaan, Abram harus melewati beberapa tempat dan tinggal selama beberapa waktu di daerah dan orang-orang serta situasi yang berbeda budaya dengan dirinya yaitu daerah Haran, Kanaan, keluar sebentar ke Mesir dan kembali Kanaan (Wahono, 2011: 96).6 Berdasarkan hal ini, penulis beranggapan bahwa perlu keterampilan atau kompetensi lintas budaya untuk melakukan perjalanan ini. Jika dikaitkan dengan kehidupan sehari-hari, maka kompetensi ini perlu dimiliki Abraham sebagai pendatang. Namun jika dilihat dari gerakan misi sentripetalnya, maka orangorang yang ada di sekitar Abraham yang harus memiliki kompetensi lintas budaya ketika bertemu Abraham. Hal ini juga yang menjadi panggilan bagi orang-orang Israel di masa PL.

6 Abram berasal dari daerah Ur. Ayah Abram, Terah, berasal dari Ur namum memutuskan pindah bersama dengan keluarganya ke Haran (Kej 11:27-32). Dalam catatan sejarah dan geografis, Ur atau Ur-Kasdim merupakan daerah di bagian Selatan Mesopotamia (Kej 11:31). Ur merupakan salah satu kota yang sangat kuat dan penting pada masa sekitar tahun 3000 S.M., dan diperkirakan menguasai hampir sebagian besar Mesopotamia Selatan (Hinson, 2012: 34-35), dan/ atau di sebelah timur Palestina (Gara, 2002: 35). Namun sekitar tahun 1950 S.M., kekuasaan bangsa ini berakhir dan kotanya dihancurkan (Hinson, 2012:35). Haran sendiri terletak di sebelah utara Palestina, yang termasuk daerah Babilonia, sekitar $900 \mathrm{~km}$ sebelah barat laut Ur Kasdim atau ujung utara Kanaan (Sikhem) sekitar $600 \mathrm{~km}$ sebelah timur laut (Gara, 2002:36) berada di wilayah Mesopotamia Barat Laut yang berdekatan dengan Mari (Kej 12:4) (Wahono, 2011:91). 


\section{c. Yunus Sebagai Misionaris Lintas Budaya}

Kitab Yunus adalah salah satu kitab yang mengkritisi ekslusivisme di Israel. Tokoh utama dalam cerita ini adalah Yunus.7 Allah memerintahkan Yunus berangkat ke Niniwe untuk menyampaikan berita hukuman.8 Bangsa ini terkenal berperilaku kejam dan tidak berbelas kasihan serta bertindak sewenang-wenang kepada bangsa yang dikalahkannya (Baxter, 2002: 208). Oleh karena itu, pandangan yang berkembang pada orang-orang Israel masa itu, adalah sesuatu yang mendatangkan sukacita besar jika Niniwe binasa (Nahum 3:1-3; 2:12; 3:19) (Baxter, 2002: 409). Bagi Yunus, bangsa Niniwe layak dihancurkan. Karena itu, ketika Allah mengutus Yunus, Yunus nekat untuk melarikan diri dari tugas tersebut. Namun hati Allah berbeda dengan hati Yunus. Allah mau, agar seperti Israel dan melalui Israel, bangsa Niniwe diselamatkan.

Kompetensi lintas budaya melalui pengalaman Yunus bukan hanya sekedar suatu usaha untuk memahami bahasa, antropologi budaya, namun juga pengurbanan diri bagi bangsa-bangsa yang belum mengenal Allah. Yunus harus bersedia untuk mengorbankan rasa superioritasnya sebagai bangsa pilihan Allah untuk menyelamatkan musuh dari bangsanya sendiri. Kompetensi seperti ini merupakan salah satu yang paling rumit untuk dilakukan oleh seorang misionaris yaitu penyangkalan diri, nasionalisme pribadi, dan kepentingan pribadi dalam misi. Kompetensi lintas budaya yang diperlukan oleh misionaris-misionaris seperti Yunus adalah kesediaan untuk mengorbankan diri dan nasionalisme pribadi untuk menyatu dengan bangsa lain agar misi Allah dapat tersampaikan.

\section{d. Amanat Yesus untuk Misi Lintas Budaya (Kis. 1:8)}

Teks ini dianggap sebagai bagian dari Amanat Agung Yesus yang ditulis oleh Lukas. Perintah Tuhan Yesus adalah agar para murid menjadi saksi lintas budaya. Hal ini terbukti melalui istilah "ujung bumi". Istilah "Ujung Bumi” merupakan istilah PL dan tidak ditemukan di luar Alkitab. Hal ini dikarenakan perspektif PL menurut Drewes, memang merupakan perspektif universal (Kej 12:3). Dalam Kisah Para Rasul, istilah ini digunakan untuk menunjuk arah pemberitaan Injil sampai akhir zaman (2014: 30-31). Ujung bumi

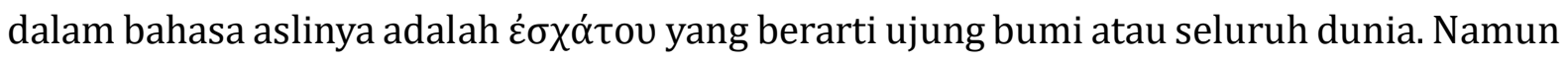
demikian, idiom ini juga memiliki arti “akhir zaman." Jadi pesan terakhir Yesus ini tidak

7 Yunus dalam bahasa Ibrani berarti Yonah yang artinya "merpati”, merupakan putra dari Amitai (Yun 1:1). Nama Amitai merupakan salah satu nama Allah yaitu "Emet-Ya" yang artinya Tuhan adalah kesetiaan (Kramer, 2013: 12). Nabi Yunus berasal dari Gat-Hefer yang terletak sekitar tiga sampai lima kilo meter sebelah utara Nazaret di Galilea. Yunus merupakan nabi di kerajaan Israel Utara pada masa pemerintahan Yerobeam II, sekitar abad ke -8 S.M., (783-743 sM).

8 Niniwe merupakan ibukota kerajaan Asyur. Ada kemungkinan kota ini dibangun oleh Nimrod (Douglas, 2007: 160-162). Niniwe merupakan kota besar dengan jarak tempuh tiga hari perjalanan (Yun 3:2), terletak di sebelah timur sungai Tigris, yakni 230 mil di utara Baghdad (masa kini). Kota ini diperkirakan berdiri tahun 5000 sM dan hancur sekitar tahun 612 s.M., karena peperangan dengan Babel dan Media (FE, 1968:333). 
hanya mengarahkan para murid untuk menjadi saksi sampai ke ujung bumi namun juga sampai kepada akhir zaman.

Bagi penulis, teks ini merupakan panggilan untuk melakukan penginjilan lintas budaya. Para murid pada umumnya merupakan orang Yahudi, sementara ujung bumi mengindikasikan adanya perbedaan budaya yang harus ditempuh oleh para murid. Untuk itu diperlukan kemampuan lintas budaya. Karena itu, Yesus memberi pesan bahwa Ia akan membekali para murid dengan kuasa kalau Roh Kudus turun ke atas mereka. Istilah kuasa dalam bahasa Yunaninya yaitu $\delta u ́ v \alpha \mu \iota v$. Dalam kaitannya dengan penginjilan lintas

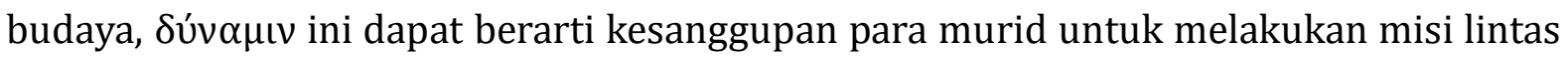
budaya. Jadi, karena Allah adalah inisiator misi lintas budaya, maka Allah sendirilah yang memberikan dan/ atau bertanggungjawab bagi para misionaris ini untuk memiliki kuasa, kesanggupan dan/ atau kompetensi dalam melakukan pelayanan lintas budaya itu sendiri.

\section{e. Peristiwa Pentakosta sebagai Gambaran Kompetensi Lintas Budaya (KPR 2:1-13)}

Dalam teks ini diceritakan bahwa para murid yang terdiri dari kedua belas rasul dan kira-kira 120 orang lain (KPR 1:15) yang adalah orang Galilea (KPR 2:7). Ketika mereka berkumpul ini, tiba-tiba muncul bunyi seperti angin keras dan lidah-lidah seperti nyala api sebagai tanda kehadiran Allah.9 Ayat 4 menunjukkan bahwa bahasa yang diberikan itu adalah "bahasa-bahasa lain" atau "bahasa kita sendiri" atau bahasa-bahasa daerah orang-orang dari suku-suku tertentu untuk memberitakan kabar baik kepada segala bangsa. Drewes menekankan bahwa bahasa yang dikaruniakan di sini berbeda dengan yang muncul dalam I Korintus 14 (2014: 45). Karena bahasa-bahasa ini dimengerti oleh orang-orang dari berbagai suku terkait sebagai bahasa ibu mereka (Drewes, 2014: 47). Orang-orang yang hadir dalam pertemuan ini menurut Drewes sebenarnya adalah orang-orang Yahudi itu sendiri namun yang tinggal menyebar di antara bangsa-bangsa di luar Yahudi.10 Bahasa merupakan bentuk komunikasi antara manusia dan bentuk nyata kekhasan masing-masing daerah. Kebutuhan mendasar

9 Ada beberapa kata penting dalam teks KPR 2:2-3 ini yaitu: 1) Angin dalam bahasa Yunaninya yaitu $\pi v o \tilde{\varsigma}$ serumpun dengan Пvєú $\mu \alpha$ yang berarti Roh. Sehingga hal ini memberi indikasi bahwa angin yang dimaksud adalah Roh. 2) Lidah dalam bahasa Yunaninya $\gamma \lambda \tilde{\omega} \sigma \sigma \alpha$ y yang berarti juga bahasa. 3) Dan api dalam bahasa

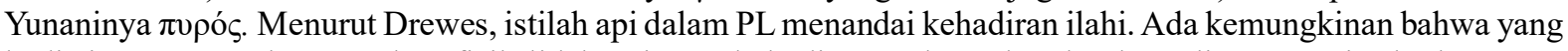
hadir itu memang kenampakan fisik lidah api atau kehadiran Roh Kudus dan kemuliaan-Nya itu berbarengan dengan karunia bahasa yang akan diberikan kepada para murid yang hadir pada saat itu. (Drewes, 2014: 44).

10 Dan mereka ini yang mewakili semua manusia atau segala bangsa. Idiom "Segala bangsa" dalam ayat 5 merupakan idiom yang biasa juga digunakan dalam PL. Memang ada bangsa-bangsa di luar kekuasaan Romawi di sebelah Timur yang disebut dalam teks yaitu Partia, Media dan Elam, di sebelah barat laut yaitu daerah Turki seperti Kapadokia dan Pamfilia, sebelah selatan yaitu Mesir dan Libia, sebelah barat yaitu ibukota Roma. Disebut juga di sana orang-orang asli Yahudi dan penganut agama Yahudi, orang Kreta dan Arab yang kemungkinan berasal dari orang pulau dan daratan. Pencatatan demikian dilakukan oleh penulis Kisah Para Rasul untuk menekankan maksud universal kabar baik itu sendiri (2014: 46-47). 
terhadap kemampuan berbahasa ditunjukkan dalam kegiatan-kegiatan para misionaris. Dan teks ini menunjukkan peran Allah sebagai inisiator misi lintas budaya dalam memberikan para misionarisnya kompetensi lintas budaya dalam bentuk bahasa yang dapat dimengerti oleh orang-orang dari berbagai budaya yang berbeda.

\section{f. Paulus sebagai Misionaris Lintas Budaya}

Paulus merupakan rasul yang paling menyuarakan misi lintas budaya sekaligus rasul yang menekankan pentingnya kerjasama misi. Pada perjalanan misi pertama, Saulus memiliki rekan sekerja yaitu Barnabas. Perjalanan pertama Paulus sebagai misionaris ini dilakukan di wilayah Asia Kecil (KPR 13-14) di sekitar Provinsi Psidia, Ikonium, Listra, Derbe, kembali lagi ke Listra, Antiokhia di Psidia, lalu berakhir di Antiokhia, Siria. Pada perjalanan yang kedua, Paulus bekerjasama dengan Timotius dan Silas (KPR 17:13-18:5). Perjalanan Paulus yang kedua meliputi Siria, Antiokhia, Derbe, Listra, Ikonium, Troas, Filipi, Tesalonika, Berea, Athena, Korintus, Efesus, Kaisarea, Yerusalem, dan kembali lagi ke Antiokhia di Siria. Dalam perjalanan kedua, muncul beberapa nama penting seperti Lidia, Priskila dan Akwila, kepala penjara Filipi, perempuan-perempuan dari golongan elit, dan Titius yang menjadi rekan sekerja Paulus dalam pelayanannya. Dalam perjalanan ketiga, ada nama Timotius dan Erastus sebagai rekan sekerja dalam pelayanan Paulus. Selain nama-nama ini, ada juga jemaat-jemaat yang menjadi pendukung Paulus dalam pelayanan seperti jemaat Antiokhia dan Filipi.

Selain itu, latar belakang Paulus yang diutus bagi orang-orang di luar komunitas Yahudi membuat Paulus harus melakukan penyesuaian terhadap beberapa isu-isu sosial dan/ atau budaya di luar Yahudi seperti: Pertama, masalah sunat. Sunat merupakan isu krusial yang dipermasalahkan di antara orang Yahudi dan Yunani pada masa itu. Orangorang Yahudi menuntut agar orang-orang Yunani yang ingin masuk dalam komunitas Kristen ikut disunat. Padahal Paulus sadar bahwa panggilannya adalah bagi orang-orang tidak bersunat. Formulasi Paulus terletak pada pentingnya Iman Kristen yang ada di hati bukan pada fisik dari sunat itu sendiri.

Kedua, masalah makanan, minuman dan hari-hari baik. Orang-orang Kristen Roma terdiri dari orang-orang yang berasal dari komunitas Yahudi dan Yunani atau nonYahudi. Bagi orang-orang non Yahudi, masalah makanan, minuman dan hari-hari baik bukan masalah dalam iman. Namun hal ini berbeda dengan yang dialami oleh orangorang Yahudi yang masuk dalam komunitas Kristen. Orang-orang Yahudi Kristen ini belum bisa melepaskan seluruhnya tradisi lama mereka, yang sudah melekat sepanjang hidup mereka, dan masih menjalaninya meskipun mereka sudah menjadi Kristen. Masalah makanan, minuman dan hari baik mutlak merupakan permasalahan budaya. Masuk atau menjadi Kristen bukan merupakan jaminan orang-orang melepaskan adat istiadat lama (End, 2015: 724-757). Teguran Paulus muncul karena ada sebagian orang 
yang mulai menghakimi satu sama lain karena masih terikat dengan tradisi-tradisi lama tersebut. Dari sini, ada upaya untuk saling menghargai dan/ atau bertoleransi satu sama lain terhadap budaya dan/ atau adat istiadat yang ada. Hal ini didasarkan pada pemahaman Paulus bahwa "Apapun yang dilakukan, lakukanlah Tuhan atau kemuliaan Tuhan." (Roma 14:8).

Kompetensi lintas budaya Paulus juga tertera nyata dalam teks I Korintus 9:2022. Dalam teks ini muncul empat kali frasa "menjadi seperti." Dalam bahasa Yunaninya, frasa ini adalah $\hat{\omega} v$. Frasa ini merupakan suatu istilah perbandingan. Paulus membuat perbandingan dirinya yang menyatakan "seolah-olah", kemiripan, persamaan, mendekati identik, dirinya dengan orang-orang Yahudi, di bawah Hukum Taurat atau tidak di bawah Hukum Taurat, lemah dan/ atau menjadi seperti mereka semua dengan tujuan keselamatan mereka. Istilah "menjadi seperti" ini menunjukkan besarnya kompetensi Paulus dalam bidang lintas budaya sebagai modal besar usaha "menyelamatkan" dan/ atau "memenangkan" orang-orang atau beberapa orang di antara mereka.

\section{Hambatan-hambatan yang Ditemukan dalam Kerjasama Misi}

\section{Faktor Perbedaan Budaya}

Faktor perbedaan budaya merupakan faktor besar yang mempengaruhi manusia dalam cara berpikir, memandang suatu persoalan, mengkomunikasikan tujuan-tujuan, dan berbagai hal lain. Perbedaan budaya juga merupakan salah satu masalah paling rumit yang terjadi dalam hubungan kerjasama antara misionaris dengan para pemimpin gereja lokal. Terutama budaya heterogen di Indonesia berbanding terbalik dengan budaya Korea Selatan yang Homogen. Karena itu, pelatihan bahasa saja, tidak cukup. Misionaris perlu belajar fenomena-fenoma dalam berbahasa dengan orang-orang lokal mulai dari kodekode dalam komunikasi non verbal, simbol-simbol, tata krama dalam pergaulan seharihari, basa-basi, sindiran, dll. Hal ini penting diketahui agar tidak terjadi kesalahpahaman yang menyebabkan ketersinggungan budaya dan berujung pada superioritas budaya dalam diri kedua belah pihak. Untuk itu, misionaris perlu mendapat bantuan para pemimpin lokal dan pelatihan untuk beberapa waktu lamanya di beberapa pusat pelatihan bahasa dan budaya Indonesia agar memiliki pemahaman dasar tentang budaya Indonesia.

\section{Perbedaan dalam Pemahaman tentang Keuangan/Asset}

Uang dan/atau asset merupakan salah satu masalah paling besar dalam kerjasama misi. Hal ini tidak hanya terjadi di antara misionaris dengan pemimpin lokal, namun di antara semua orang. Namun dalam kasus misionaris Korea di Indonesia, persoalan yang 
paling sering terjadi antara lain:

Pertama, kesalahpahaman tentang sumber keuangan misionaris. Ada banyak kasus yang muncul karena faktor keuangan. Kasus-kasus ini bersumber dari kecemburuan yang bersumber dari kesalahpahaman di antara pihak-pihak yang bekerjasama. Misionaris terkesan memiliki gaya hidup mewah saat di Indonesia. Penulis melihat bahwa selama ini, telah terjadi kekeliruan dalam memahami sistem keuangan misionaris dari pihak pemimpin lokal Indonesia.11 Departemen Misi Sinode PCK memang telah menjaminkan semua kebutuhan misionaris sesuai dengan standar upah di Korea Selatan. Perbedaan nilai tukar mata uang Korea - Indonesia dan harga barang dan jasa yang lebih rendah di Indonesia membuat kesan gaya hidup mewah para misionaris ini semakin menonjol. Hal ini berbanding terbalik dengan para pemimpin gereja lokal di daerah yang hidup sederhana tanpa kendaraan dan rumah yang layak.

Kedua, superioritas dalam diri misionaris. Beberapa misionaris secara alami memiliki rasa superioritas serta kecenderungan ingin mengatur orang-orang lokal terutama bila mereka menjadi salah satu pendukung utama keuangan gereja lokal. Hal ini cukup membahayakan dalam hubungan antara misionaris dengan pemimpin lokal. Namun hal ini murni berkaitan dengan emosional pribadi yang muncul secara alami dalam diri seseorang dalam bentuk harapan untuk dihormati atas prestasi yang sudah dibuat.

Ketiga, tidak adanya laporan pelayanan dalam kerjasama. Keengganan untuk memberikan laporan yang transparan kepada semua anggota yayasan penanggung jawab pelayanan membuat prasangka negatif terhadap para misionaris atau sebaliknya. Sampai saat ini, memang tidak banyak misionaris yang melaporkan kepada anggota tim yang bekerjasama tentang berapa besar dana untuk suatu program tertentu. Hal ini karena dana yang dikucurkan dari pihak sponsor biasanya sesuai dengan yang tercantum pada proposal atau yang telah diprogramkan. Namun untuk menjaga nama baik dan menghindari prasangka negatif sebaiknya laporan itu harus disiapkan. Masalah ini pernah terjadi di beberapa wilayah pelayanan misi di Indonesia dan telah menimbulkan konflik di antara pihak yang bekerjasama.

Keempat, kesulitan dalam mengkomunikasikan pemahaman tentang kerjasama. Umumnya, setiap orang dalam bekerjasama mengharapkan adanya suatu take and give di antara kedua belah pihak. Take and give ini muncul misalnya ketika misionaris yang bekerja di Indonesia mengharapkan mendapatkan wadah yang cocok sebagai sarana

11 Ada anggapan bahwa misionaris dan keuangan misionaris didapat berdasarkan hasil kerja mereka di Indonesia. Ungkapan lain misalnya bahwa para misionaris hidup dengan nyaman di Indonesia karena "menjual" nama atau foto-foto orang Indonesia. Faktanya, memang ada gap gaya hidup antara misionaris dengan para pemimpin gereja lokal terutama di daerah-daerah. Misalnya, tempat tinggal yang baik ataupun kendaraan sesuai standar sinode PCK di Korea Selatan bukan di Indonesia. Hal ini memunculkan kesan bahwa para misionaris hidup mewah saat berada di ladang misi. 
dalam pelayanan misinya, sementara rekan kerja misionaris mengharapkan adanya sumbangsih materi dan keahlian dari pihak misionaris terhadap organisasi mereka.12

Kelima, perbedaan dalam cara menggunakan dan mengelola uang/ asset misi. Biasanya, pada saat pengajuan proposal dikabulkan pihak sponsor akan menitipkan sejumlah besar uang sesuai proposal kepada misionaris. Untuk itu, dana yang diberikan, harus dipergunakan sesuai dengan rancangan proposal tersebut. Hal ini berbanding terbalik dengan kebiasaan orang-orang Indonesia yang mempergunakan dana sponsor untuk kepentingan mendesak terlebih dahulu tanpa mengkomunikasikan dengan misionaris. Penyalahgunaan atau kebiasaan pengalihan dana menyebabkan para misionaris enggan untuk mempercayakan uang misi untuk dikelola langsung oleh pemimpin lokal.

\section{Pola Relasi dalam Kehidupan Sehari-hari}

Ada beberapa fakta lapangan yang memicu permasalahan dalam hubungan kerjasama misionaris dengan pemimpin lokal Indonesia, seperti:

Pertama, membangun relasi dengan pemimpin lokal. Seringkali muncul perasaan superior di antara para misionaris terhadap pemimpin lokal. Entah karena tingkat pendidikan yang lebih tinggi, usia, pengorbanan yang diberikan, ketersinggungan budaya yang tidak tuntas, konflik-konflik tim yang tidak selesai, kepercayaan yang hilang, dll membuat hubungan baik antara misionaris dan pemimpin lokal rusak. Bagaimanapun, tidak ada hubungan yang berjalan lancer tanpa konflik. Untuk itu, perlu persekutuan yang erat dan komitmen bersama dalam menyelesaikan persoalan-persoalan yang ada demi tercapainya visi dan misi kerjasama.

Kedua, ketidakmampuan dalam membaca maksud tersembunyi dari komunikasi verbal dan nonverbal para pemimpin lokal. Di Indonesia terdapat banyak Bahasa-bahasa kiasan yang jika tidak teliti, maka akan menimbulkan kesalahpahaman dengan orangorang asing. Misalnya, jika orang Indonesia mengatakan kata "Kemarin" maka bisa saja "kemarin" yang mereka maksud adalah seminggu yang lalu, sebulan yang lalu, setahun yang lalu, bahkan bertahun-tahun yang lalu. Demikian, juga dengan kata "besok". Kata "besok" dalam terjemahan Bahasa Inggrisnya adalah "tomorrow". Namun digunakan oleh orang Indonesia untuk menyebut waktu di masa depan dengan jangka waktu yang tidak

12 Contoh yang baik dapat dilihat dalam kerjasama dengan sinode GIA. Sinode GIA tidak hanya menjamin visa dan menyediakan tempat pelayanan namun juga membantu agar program misi di suatu wilayah pelayanan misi berlangsung dengan baik. Mantan Ketua Sinode GIA, Pdt. Samuel (Alm), dalam pertemuan dengan penulis menjelaskan rancangan kerjasama di antara sinode GIA dengan sinode PCK dalam hal dana program untuk pelayanan di suatu wilayah tertentu. Sinode GIA dalam hal ini membagi tanggungjawab 50:50 dana dari sinode GIA dan sinode PCK sehingga tidak memberatkan pihak misionaris. Take and give lain misalnya dengan saling berbagi pergumulan-pergumulan pelayanan dan pokok doa sehingga menimbulkan rasa saling memiliki dalam tim dan ikatan emosional yang kuat, sesama anggota tim bisa saling menguatkan, dan membangun rasa saling percaya di antara masing-masing anggota. 
terhingga.

Ketiga, peledakan emosi karena penumpukan masalah-masalah kecil. Masalahmasalah kecil seperti cara bicara dan tindakan yang umum di Korea namun kurang layak bagi pemimpin Indonesia, sikap superioritas yang semakin lama semakin jelas, perbedaan dalam pengelolaan keuangan, dll. Untuk itu, kedua belah pihak perlu mengambil langkah bijak, duduk bersama, untuk menyelesaikan persoalan yang ada. Untuk itu, perlu sikap terbuka, rendah hati, mau saling mendengarkan, saling mengoreksi, dan terutama saling mengampuni agar hubungan kerjasama ini tetap berjalan baik. Misionaris mengalami berbagai persoalan di ladang misi baik dengan rekan sesama misionaris, gereja lokal dan dengan keluarga.

Empat, Luka Internal. Di beberapa tempat, tidak ada alternatif konkret bagi pendidikan anak-anak di sekolah internasional maupun sekolah lokal. Belum lagi, perasaan sendiri dan frustasi yang dialami oleh misionaris karena penyakit, ditambah hubungan yang kurang baik dengan sesama misionaris dan pemimpin lokal, kekacauan program, adaptasi budaya, membuat tekanan besar dalam diri keluarga misionaris. Ketiadaan dukungan moral bagi para misionaris yang bekerja di garis depan menyebabkan perasaan sendiri dan kesulitan dalam menyembuhkan luka internal (홍인식_Hong In Sik, 2010: 135). Biasanya, misionaris Korea memiliki tekanan pribadi karena gereja sponsor terlalu memaksakan program pelayanan tanpa pemahaman yang benar tentang ladang misi itu sendiri. Hal ini menimbulkan banyaknya tabrakan kebijakan dengan para pemimpin lokal. Di sisi lain, ada beberapa misionaris yang mencoba untuk berkontekstualisasi dengan kebutuhan di ladang misi, namun diperhadapkan dengan ancaman pemutusan hubungan kerjasama dengan gereja sponsor. Pilihan sulit ini menghantarkan misionaris pada relasi yang kurang baik pada gereja sponsor atau gereja lokal.

\section{Kurangnya Evaluasi Kerjasama Misi Lintas Budaya}

Permasalahan yang dihadapi para misionaris selama berada di ladang misi seharusnya tidak menjadi persoalan misionaris pribadi melainkan persoalan gereja dan misi. Baik gereja sponsor maupun gereja perekrut perlu mengidentifikasi dan menganalisis persoalan-persoalan yang dihadapi para misionaris di ladang misi. Hal ini dapat dilakukan melalui evaluasi. Namun kurangnya evaluasi kerjasama misi selama ini membuat banyak hasil kerja serampangan atau tidak tepat sasaran menjadi berulang kali terjadi di lapangan bahkan dapat menimbulkan salah paham baru di antara kedua belah pihak yang bekerjasama. 


\section{Hasil: Upaya Peningkatan Kompetensi Kerjasama Misi Lintas Budaya Misionaris PCK dengan Pemimpin Gereja Lokal Indonesia}

\section{Menentukan Prospek Kerjasama Misi Lintas Budaya}

Keterbatasan kompetensi lintas budaya membuat prospek paling baik yang ditawarkan adalah kerjasama. Untuk itu, ada beberapa kriteria penting:

\section{Kesepahaman dalam Teologi dan Kerjasama Misi}

Di ladang misi terdapat berbagai denominasi gereja seperti gereja-gereja ekumenis, gereja dengan teologi liberal, gereja dengan teologi konservatif, gereja Pentakosta, dll. Di sisi lain, beberapa gereja misionaris atau gereja pengutus memiliki teologi konservatif yang berlebihan, tertutup, dan eksklusif. Denominasionalisme yang berlebihan akan menyebabkan kesulitan dalam kerja sama misi antara gereja penerima misionaris dan misionarisnya.13 Untuk itu, diperlukan kesepahaman teologi di antara kedua belah pihak.14 Penulis melihat ada dua alternatif yang bisa dipilih, pertama, misionaris perlu memiliki kemampuan atau pemahaman teologis yang baik untuk memetakan persoalan teologis yang dapat menimbulkan permasalahan dalam pelayanan dengan para pemimpin dan orang-orang atau jemaat lokal.15 Atau kedua, akan lebih baik jika kerjasama dilakukan dengan gereja-gereja yang memiliki latarbelakang teologis yang sama dengan gereja sponsor dan dengan misionaris itu sendiri.

Di lain pihak, sebagai partner atau rekan kerja, misionaris dan pemimpin lokal berperan sebagai mitra yang sejajar. Sejajar berarti tidak ada yang lebih superior di antara kedua belah pihak. Kedua belah pihak bekerja bersama-sama dalam ikatan saling percaya, saling menjaga, dan saling menghormati. Selain itu, kedua belah pihak juga memiliki hak dan kewajiban yang sama, saling memberi dan saling menerima. Hal ini bukan hanya tentang kesepakatan dalam tanggungjawab materi melainkan juga berbagi pikiran dan

13 Sebagai catatan, misionaris Korea yang dikirim ke ladang misi diutus sesuai dengan latar belakang gereja mereka masing-masing. Ada misionaris yang hanya diutus oleh satu gereja, ada yang diutus oleh satu klasis, dan ada yang diutus oleh badan misi. Organisasi gereja pengutus dan organisasi-organisasi misi ini memiliki kecenderungan teologis yang berbeda meskipun masih dalam satu sinode. Sebagai catatan, di Korea, satu klasis dapat terdiri dari 130 gereja Presbiterian (위의 글_Wiui Geul, 197-198)

14 Kesepahaman yang penulis maksud bukan supaya di antara kedua belah pihak harus memiliki warna teologi yang sama namun lebih kepada pembicaraan awal atau komunikasi pada masa prakerjasama tentang perbedaan ataupun persamaan dalam praktik teologis dan misi di antara kedua belah pihak yang mungkin akan mempengaruhi dalam praktik misi.

15 Sebagai informasi, sebenarnya, salah satu kriteria para misionaris yang diutus ke Indonesia adalah kualifikasi pendidikannya. Para misionaris yang diutus ke Indonesia umumnya merupakan tenaga ahli dalam bidangnya dan berpendidikan minimal Magister. Pengaturan kualifikasi ini berbeda dengan yang terjadi di negaranegara lain di ladang misi. 
perasaan (emotion sharing) agar terjalin ikatan emosional antara misionaris dengan pemimpin lokal.

\section{Kepribadian Misionaris}

Buah dari pekerjaan misionaris paling banyak muncul dari aspek personal misionaris ketimbang teologi ataupun strategi yang digunakan. Hal ini karena ternyata banyak misionaris yang tampaknya kompeten dalam misi ternyata memiliki banyak cacat Alkitab (Schubert, 1991: 33-36). Untuk itu, misionaris sebaiknya memiliki beberapa kriteria penting seperti hidup saleh, kasih dan ketaatan, gairah (Passion) dalam melayani, dan kerendahan hati dan keterbukaan dalam bekerjasama.

\section{Komposisi Tim Kerjasama yang Baik}

Kerjasama misi adalah kerjasama tim sehingga segala sesuatu penting untuk dikomunikasikan, diprogramkan dan dikerjakan bersama dalam tim. Untuk itu, perlu dibuat komposisi tim yang jelas, sistem kerja yang jelas dan terbuka, langkah-langkah tepat dalam mengatasi berbagai konflik dan memperkuat kerjasama, sikap saling rendah hati dan terbuka untuk masukan, mau mengampuni dan tetap pada komitmen kerjasama sampai tujuan dari kerjasama lintas budaya tercapai. Agar tim ini dapat berjalan harmonis, tim perlu memiliki seorang leader yang mampu memimpin para pemimpin lainnya. Pemimpin tersebut adalah orang yang memiliki keahlian dalam berkomunikasi (Kim, 2016: 393-397), paham tentang situasi pelayanan di Indonesia, memiliki koneksi baik dengan para pemimpin lokal, masyarakat dan pemerintah lokal, memiliki kemampuan administrasi yang baik, mampu mengakomodir setiap masukan dengan baik, dll. Untuk itu, ada baiknya jika pemimpin yang dipilih dalam tim kerjasama misionaris dan pemimpin lokal adalah salah satu dari pemimpin lokal yang ada di Indonesia.

\section{Penyusunan Langkah-langkah Strategis dalam Kerjasama Misi}

Untuk dapat melaksanakan kerjasama misi lintas budaya dengan baik, perlu dilakukan langkah-langkah strategis dan spesifik seperti:

\section{Mengemukakan Visi Misi Kerjasama Misi Lintas Budaya}

Kerjasama lintas budaya dilakukan oleh dua kelompok atau lebih dari organisasi dan kebudayaan yang berbeda. Oleh sebab itu, kedua belah pihak harus terlebih dahulu menjabarkan visi misi mereka secara lugas. Hal ini penting untuk menentukan arah dan/atau tujuan dari kerjasama ini dan pendekatan atau stategi yang dipilih dalam pelaksanaan program kerjasama. Untuk memenuhi visi ini, perlu disusun sasaransasaran, target dan/atau misi yang jelas dan konkret dalam pencapaiannya. Visi 
kerjasama ini bukanlah untuk kepentingan satu pihak namun demi kepentingan bersama terutama kemajuan pelayanan di gereja lokal. Setelah kesatuan visi misi di dapatkan, maka peresmian hubungan kerajsama dapat dilakukan.

\section{Pembuatan MOU}

Sampai saat ini, tidak banyak pemimpin lokal Indonesia yang sudah secara resmi melakukan penandatangan kerjasama di antara mereka dalam bentuk MOU. Padahal menurut penulis, beberapa kasus yang terjadi dalam kerjasama misionaris dengan pemimpin gereja lokal dapat diselesaikan berdasarkan MOU. MOU menjadi bentuk legalitas kerjasama di satu sisi dan menjadi catatan sejarah kerjasama yang memungkinkan adanya hubungan kerjasama berkelanjutan meskipun para penanda tangan MOU sudah tidak ada. Ada dua jenis kesepakatan dalam kerjasama yaitu MOU kerjasama untuk menyatakan hubungan antara kedua belah pihak dan MOU program. MOU program bersifat lebih spesifik baik dalam bentuk job description maupun dalam bentuk evaluasi atau laporan berkala. Program ini dapat dibuat bersama-sama oleh kedua belah pihak.

\section{Pembuatan Sistem yang Jelas}

Setelah melakukan MOU kerjasama maka langkah selanjutnya adalah pembuatan sistem. Sistem ini berupa peraturan-peraturan dalam kerjasama yang disepakati oleh kedua belah pihak. Untuk itu, sistem ini pemimpin lokal perlu diuraikan secara spesifik. Sistem yang kuat menjamin hubungan kerjasama yang baik, tercapainya tujuan, dan meminimalisir konflik di antara kedua belah pihak. Kedua belah pihak mungkin memiliki kekuatan masing-masing namun keduanya tidak boleh melawan sistem yang telah ditetapkan bersama.

\section{Memperkuat Komitmen untuk Berelasi atau Ikatan Persekutuan}

Relasi antara manusia merupakan elemen paling penting dalam bekerjasama. Relasi yang erat antara misionaris Korea dan pemimpin lokal membuat kedua belah pihak mampu mengatasi kesulitan-kesulitan dan perbedaan-perbedaan yang ada dalam ladang pelayanan. Seringkali timbul konflik dalam kerjasama, untuk itu, masing-masing pemimpin perlu bersikap rendah hati, saling mengampuni, saling percaya, saling menghargai atau menghormati dan banyak menyangkal diri. Hal ini bisa dilakukan melalui komunikasi dengan pembuatan program bersama, tukar menukar atau saling interaksi dan/ atau bertemu dalam berbagai acara, banyak bergaul dengan rekan kerja, para pendeta dan dosen-dosen lain. Selain itu, diperlukan komitmen kuat untuk bertahan dalam kerjasama. Komitmen membantu setiap anggota tim untuk tetap bertahan di tengah perbedaan-perbedaan yang ada agar tetap berfokus pada visi organisasi. 
Komitmen ini didasari kasih, kerendahan hati dan kesediaan untuk saling mengampuni atau memaafkan.

\section{Evaluasi}

Sampai saat ini, hampir-hampir tidak ada catatan tentang evaluasi kerjasama antara misionaris dengan pemimpin lokal. Padahal evalusi merupakan salah satu kriteria penting dalam pelaksanaan program. Evaluasi umumnya dilakukan antara orang-orang atau kelompok dalam organisasi dengan duduk bersama, berembuk, menilai pengalaman program berkala di periode sebelumnya, mengkritisi, dan memberikan catatan-catatan penting untuk program dikemudian hari. Evalusi program dilakukan berpatokan para MOU program yang telah dibuat sebelumnya. MOU program ini dapat diperbaharui secara berkala setiap periode program berdasarkan kesepakatan kedua belah pihak. Untuk itu, masing-masing anggota tim perlu mempersiapkan laporan-laporan pertanggungjawaban hasil kerja mereka untuk dijadikan evaluasi bersama. Kegagalan pelaksanaan program satu orang dalam tim bukanlah kegagalan satu orang saja namun kegagalan tim secara keseluruhan, karena itu, evaluasi yang dilakukan dapat menjadi peluang yang baik untuk memperbaiki kesalahan-kesalahan dalam program sebelumnya agar berjalan lebih baik lagi di masa depan.

\section{Upaya Peningkatan Kompetensi Lintas Budaya Misionaris PCK}

Ada beberapa poin penting yang menjadi tugas bersama para misionaris dan pemimpin lokal untuk dapat meningkatkan kompetensi lintas budaya, antara lain:

\section{Seleksi Calon Misionaris untuk Pelayanan Lintas Budaya}

Faktanya adalah bahwa tidak semua hamba Tuhan dalam jajaran sinode PCK siap untuk diutus sebagai misionaris lintas budaya. Karena itu, sinode PCK perlu melakukan seleksi terhadap para hamba Tuhan PCK yang berkompetensi untuk menjadi misionaris lintas budaya. Selama masa penyeleksian, diadakan pelatihan-pelatihan. Pelatihan ini bertujuan menanamkan kesadaran terhadap pentingnya kerjasama misi, penjelasan spesifik terhadap tujuan dan metode kerjasama misi, dan membangun kemampuan menciptakan metode dan cara-cara yang cukup bagi kerjasama misi lintas budaya.

\section{Briefing Budaya Indonesia Di Korea}

Pada tahap awal, sebelum memasuki Indonesia, sebaiknya sinode PCK melakukan pengenalan budaya awal Indonesia kepada para calon misionaris yang akan diutus. Pada tahap ini, gereja pengutus memperkenalkan terlebih dahulu gambaran tentang Indonesia dan budaya Indonesia. Untuk itu, gereja sponsor mungkin perlu melakukan kerjasama 
dengan orang-orang Indonesia yang ada di Korea untuk melakukan pelatihan tentang budaya Indonesia, atau meminta tenaga utusan khusus ke Korea dari sinode yang direncanakan akan melakukan kerjasama dengan gereja pengutus misonaris, atau bisa juga dari para misionaris senior yang pernah bertugas di Indonesia.

\section{Pendidikan dan Pelatihan Bahasa}

Pendidikan dan/atau pelatihan bahasa merupakan hal dasar bagi para misionaris yang diutus ke Indonesia. Untuk itu, sinode PCK membuat kebijakan agar para misionaris mengikuti pelatihan bahasa dan budaya Indonesia terlebih dahulu sebelum masuk ke ladang misi. Di Indonesia, biasanya ada dua tempat yang paling sering dipilih oleh para misionaris untuk pelatihan bahasa yaitu di IMLAK Bandung dan Universitas Indonesia di Jakarta.16 Selanjutnya, misionaris perlu terus mengasah kemampuan berbahasanya dengan cara terlibat langsung dengan orang-orang Indonesia.

\section{Pengenalan Budaya Lanjutan}

Bagian akhir yang tidak kalah penting adalah belajar budaya secara langsung di bawah bimbingan pemimpin lokal. Pembelajaran budaya tidak bisa dilakukan hanya secara umum karena masing-masing daerah di Indonesia memiliki perbedaan dan/ atau kekhasan budaya. Pemimpin gereja lokal perlu memperkenalkan budaya setempat baik dalam hal kebiasaan-kebiasaan atau etika hidup dan bergaul sehari-hari, bahasa atau jargon-jargon sehari-hari, makanan, cuaca, prakiraan biaya hidup, dan hal-hal praktis lain. Briefing budaya merupakan bagian praktis dalam kerjasama dan terjadi secara berkelanjutan. Para misionaris perlu aktif dalam bertanya kepada para pemimpin lokal jika mengalami kebingungan budaya. Cara ini membantu misionaris untuk memperoleh gambaran atau pola budaya Indonesia terkhusus khasanah lokalnya dan mengurangi culture shock terhadap daerah yang akan dimasuki.

\section{Keterlibatan Aktif Misionaris dengan Kegiatan Sosial Masyarakat}

Ada suatu perbandingan besar yang mengejutkan di antara para misionaris Korea masa kini dengan misionaris barat di masa lalu. Perbandingan ini muncul dalam suatu pertanyaan sekaligus wacana yang disampaikan yaitu "Mengapa para misionaris barat di masa lalu dapat berbicara dengan fasih dalam bahasa Sunda, Jawa, Melayu, atau bahasa-

${ }_{16}$ Pelatihan umumnya dilakukan selama satu sampai dua tahun. Di tempat pelatihan ini, misionaris tidak hanya diajari bahasa Indonesia namun juga budaya Indonesia. Pada bagian akhir pelatihan, para misionaris umumnya diminta membuat makalah tentang budaya Indonesia. Selain itu, hal ini juga rupa-rupanya telah diatur dalam Peraturan Menteri Ketenagakerjaan Republik Indonesia No 1 Tahun 2018 tentang Tata Cara Penggunaan Tenaga Kerja Asing dalam pasal 4 ayat 4 poin (g) yang berisi ketentuan bahwa setiap Pemberi kerja TKA wajib memfasilitasi pendidikan dan pelatihan Bahasa Indonesia kepada TKA yang dipekerjakannya beserta beberapa ketentuan lain. 
bahasa daerah lain di Indonesia, sementara misionaris Korea tidak?" Pertanyaan sekaligus pernyataan ini menjadi suatu kritik besar bagi misionaris Korea yang bertugas di Indonesia masa kini sekaligus pembakar semangat para misionaris untuk terus belajar bahasa lokal. Untuk persoalan ini, penulis beranggapan bahwa jalan keluar yang baik adalah dengan melibatkan diri secara pada situasi kehidupan sehari-hari masyarakat Indonesia. Pertemuan dengan orang-orang lokal baik positif maupun negatif membuat proses belajar budaya ini menjadi lebih cepat. Untuk itu, pelru sikap terbuka dalam menerima perbedaan dalam budaya saat bertemu langsung dengan orang-orang lokal.

\section{Kesimpulan}

Kerjasama misi yang baik dapat dicapai jika pihak-pihak yang bekerjasama mau mengusahakannya. Memang kerjasama ini bukanlah suatu pekerjaan yang mudah, untuk itu kedua belah pihak perlu bertahan dalam komitmen kerjasama yang ada. Ada berbagai langkah yang penulis sudah cantumkan dalam jurnal ini, namun tentu ini bukanlah formula akhir. Selama kerjasama misi ini masih berjalan dan terus berkembang, maka formula-formula baru akan bermunculan di hari-hari ke depan.

\section{Referensi}

Choi Yong Sung.

2019 "Kompetensi Kerjasama Lintas Budaya Misionaris Korea dengan Pemimpin Lokal Indonesia" Misiologi, STA Tiranus, Bandung. 